\title{
Publishing the "invisible" language - some influences on Ulster-Scots publishing in the modern revival period
}

\section{Anne Smyth}

\section{(2) OpenEdition}

\section{Journals}

Electronic version

URL: http://journals.openedition.org/etudesirlandaises/3494

DOI: 10.4000/etudesirlandaises.3494

ISSN: 2259-8863

Publisher

Presses universitaires de Rennes

Printed version

Date of publication: 20 December 2013

Number of pages: $27-40$

ISBN: 978-2-7535-2887-1

ISSN: 0183-973X

\section{Electronic reference}

Anne Smyth, «Publishing the "invisible" language - some influences on Ulster-Scots publishing in the modern revival period », Études irlandaises [Online], 38-2 | 2013, Online since 20 December 2015, connection on 05 May 2019. URL : http://journals.openedition.org/etudesirlandaises/3494 ; DOI 10.4000/etudesirlandaises.3494

This text was automatically generated on 5 May 2019.

(c) Presses universitaires de Rennes 


\title{
Publishing the "invisible" language - some influences on Ulster-Scots publishing in the modern revival period
}

\author{
Anne Smyth
}

\section{Introduction}

1 This paper will examine the motivations and pressures that have shaped the approach to publishing in Ulster-Scots, which has Part 2 status under the European Charter for Regional or Minority Languages ${ }^{1}$, ratified by the United Kingdom Government on the $27^{\text {th }}$ of March 2001. Our period of interest coincides with the life of the Ulster-Scots Language Society (USLS), founded in 1992, the first Ulster-Scots language group. During the intervening twenty years, the USLS has published upwards of 30 books and periodicals.

\section{Structural context}

2 Compliance with the Charter is not mandatory for subscribing governments. However, the effects of the other major government instrument that changed the dynamics with regard to minority languages in Northern Ireland have been much more pervasive. Agreed on 10 April 1998, this measure is unique in having both an internal and an international aspect, in creating institutions that operate across the UK/Irish border, and in being popularly known by two different names, one mainly used by the broadly unionist community, "The Belfast Agreement", and the other mainly used by the broadly republican community, "The Good Friday Agreement ${ }^{2}$. This constitutional arrangement was loosely framed so as to enable each faction" to promote the deal to its own particular electorate in a way that suited the aspirations of each. The details of its operation, 
however, consequently lacked definition, and its implementation has been marked by much confusion and inventiveness.

3 So far as Northern Ireland's indigenous minority languages are concerned, the most significant outcome was the creation of the "North-South Language Body", which comprises two elements, "Foras na Gaeilge" and "Tha Boord o Ulstèr-Scotch". The structure thus formed is inherently unequal, as the Board membership of the former is twice the size of that of the latter.

4 Two other structural considerations of major importance bear upon the effectiveness of these Boards: firstly, Foras na Gaeilge is a language body, which does not imply that it does not fund cultural projects but rather that the Irish language is its primary concern; meanwhile, the remit of Tha Boord o Ulstèr-Scotch is support for both culture and language, which has in practice worked greatly to the detriment of language. Secondly, the three components that make up Foras na Gaeilge were already established organisations operating throughout the island, supported by the Republic of Ireland government, well before the Belfast/Good Friday Agreement. On the implementation of the Agreement, therefore, the staff of Bord na Gaeilge, An Gúm (its publishing arm) and An Coiste Téarmaíochta (Terminology Committee) and their activities were all simply transferred to the new body, jointly funded by the UK and Irish governments.

5 The organisational structure of Foras na Gaeilge now comprises a Directorate of Publishing, Lexicography and Terminology, in which are located the publishing body, An Gúm, the English/Irish Dictionary Project, and the Terminology Committee, all of which have been active and effective in support of Irish. In contrast, there has been no sign that the Boord appreciates the need to create similar institutions, with a similarly high profile, for the Ulster-Scots language.

6 The other important point to note concerns the nature of the personnel on the Boards. With three exceptions out of a Board of 16, members of An Foras use the Irish form of their names, leading to the natural assumption that they are Irish speakers. Conversely, on the current Boord o Ulstèr-Scotch there is not one single Ulster-Scots speaker, although there has occasionally been one on past Boords. The Boord cannot draw upon any internal knowledge of what is needful for the protection and promotion of the language, nor does it engage with the Ulster-Scots speaking community.

7 It follows, therefore, that while Foras na Gaeilge has continued to be effective in promotion of the Irish language, the absence of committed component organisations and personnel has militated against similar progress on the Ulster-Scots side.

While the function of the Irish and Ulster-Scots Boards (whose members are political appointees) is to determine policy, paid employees are responsible for administration which in the case of Ulster-Scots is done by the Ulster-Scots Agency. However, one looks in vain for any department or officer within the Agency whose job description includes either publishing or terminology. Furthermore, familiarity with the Ulster-Scots language is not required for recruitment to Agency posts. It is this Agency and its Board that today fund Ulster-Scots publishing, either through project funding or by way of their four corefunded groups, of which the Language Society is one, although the Society is a founder organisation of another core-funded group, the Ulster-Scots Community Network, formerly the Ulster-Scots Heritage Council, originally intended to be an umbrella body for the sector's culture and language groupings. 


\section{Funding Ulster-Scots publications}

9 In Scotland those involved in Scots language activity unfavourably contrast the apparently generous financing of Ulster-Scots publications out of the public purse with their own position. However, a previous Chief Executive of the Ulster-Scots Agency once admitted to the writer that the Agency's main objective was to promote itself to the public; in so doing it has given a wrong impression of the extent of its largesse. To all intents and purposes, responsibility for publishing Ulster-Scots language material has largely fallen upon the Ulster-Scots Language Society, which for most of its life has operated as a voluntary body with charitable status. All writing, editing and preparation for publication have been undertaken on a voluntary basis, with Language Society members giving freely, and often sacrificially, of their time and talent. Nevertheless, design, page setup and printing services still must be procured. Prior to the creation of the North/South Language Body, the financial support for these elements was provided by the Cultural Traditions Programme, which is no longer active, or by the Arts Council of Northern Ireland. Thereafter, funding for Ulster-Scots publishing projects was in practice largely left to the Ulster-Scots Agency and Boord.

The Cultural Traditions Programme was an initiative of the Cultural Traditions Group (CTG). For its origins we must go back to 1987, when the Westminster Government set up the Central Community Relations Unit. This was an exercise in social engineering, originating with the government's analysis of the "Northern Ireland Problem", and the unit's remit was the ending of religious discrimination and the promotion of better community relations. As matters of culture and heritage progressively occupied more of its attention, the subsidiary CTG gained official status and organised a number of conferences, including those whose titles began with "Varieties of...". These examined "Irishness" in 1989, "Britishness" in 1990 and "Scottishness" in 1996". When, in 1990, the Northern Ireland Community Relations Council (NICRC) was set up as a publicly-funded body administering grant aid, the CTG became part of this new body with responsibility for organising events and dealing with applications for funding. The CTG sub-group appears to have ceased operating, and its functions to have reverted to the main NICRC. So far as the rationale for their existence is concerned, it has been argued that "this sort of cultural policy inadvertently reinforces the kind of closed cultural isolationism it aims to change".

12 Whatever its motivations, funding from the Cultural Traditions Programme enabled the newly-formed Ulster-Scots Language Society to publish the first issue of its in-house journal, Ullans, in Spring 1993. The aim of the Society was summed up in the frontispiece as "to promote the status of Ulster-Scots as a language, and to re-establish its dignity as a language with an important part to play in our cultural heritage 5 ".

\section{Choosing the material}

The Society's statement of its aim immediately hints at competing priorities held in tension. Native speakers frequently remark that as young people in the education system they were made to feel that the language they spoke was a crude slang that would militate against their prospects of employment, and of which they should be ashamed. 
Indeed, similar pressures remain today. The Society's mission has therefore been to counteract such attitudes and work towards making the use of Ulster-Scots acceptable in all social contexts as a language of which people can be proud. However, the Society also exists for the benefit of native speakers, for whom the "tongue" is rural, spoken rather than written, highly localised so far as variant forms are concerned, and redolent of older ways of life. As a body, the USLS has therefore often found itself advocating an outwardfacing approach, involving lobbying, modern terminology, teaching aimed at those for whom it is not a first language, creation of language resources, etc., while also trying to keep the native speakers, largely uninterested in these issues, committed to the Society. In Northern Ireland there is also a strong tendency towards anti-intellectualism, which is mirrored in the main unionist party, the Democratic Unionists. Within the Ulster-Scots Language Society, an anti-academic bias has resulted from the appearance of excessively hostile articles in publications that examine the language issue from a pseudosociopolitical viewpoint ${ }^{6}$.

14 The Language Society's choice of material for publication reflects these disparate emphases. Ullans has now reached its thirteenth issue. Its editors have always tried to achieve a balance between the didactic and the entertaining. So far as the Society's publications list in general is concerned, however, the two best-sellers are The Hamely Tongue: A Personal Record of Ulster-Scots in County Antrim ${ }^{7}$ and Ulster-Scots: A Grammar of the Traditional Written and Spoken Language ${ }^{8}$. The former is an extended glossary limited to County Antrim, researched by a now-retired school principal over a protracted period beginning in the 1960s. No general historical dictionary of Ulster-Scots is yet available. It is remarkable that out of the booklist of The Ullans Press (the Language Society's imprint), it is two rather more learned books that have attracted public attention. Conversely, although the two authors are also poets of some distinction, their books of poetry have not achieved similar popularity ${ }^{9}$.

\section{Quality control}

15 Another factor in the choice of material for publication is writing quality. The natural emphasis for the Society is on the publication of texts in which Ulster-Scots grammar and vocabulary are faithfully represented and in which there is a high proportion of material of linguistic interest. Desirable as it is to give public exposure to densely Ulster-Scots text, however, the competing consideration is the need to hold the attention of the reader. The Ulster-Scots sector has seen the production of much doggerel (rather than poetry) and much poor writing generally. Engaging the reader of Ullans with excerpts from the historic writings is not assisted by the often mundane choice of subject matter, by "Weaver Poets" and the writers of the "Kailyard Novels", for example. Even the Weaver Poet most praised today, James Orr of Ballycarry (1770-1816), chose to write an ode "To the Potato ${ }^{10}$ ", full of interesting vocabulary but hardly exciting for the modern reader. No credit, however, can be taken by the current generation of writers, as their fondness for nostalgia can likewise be discouraging to today's readers.

16 In addition to giving current readers access to sample texts from the historic writers, the Society showcases modern Ulster-Scots writing. Early issues of Ullans were edited with a light touch, following the policy that so long as there was internal consistency in spellings the editors did not wish to be too prescriptive. After all, it was argued, writing in Ulster-Scots was an activity that had waxed and waned over the generations, and the 
present generation was going through a learning process. Ulster-Scots has no official presence within Northern Ireland's education system, except as part of a numinous concept, "Ulster-Scots Awareness ${ }^{11}$ ", written into various government policies. It is not taught as a language at any level.

Provision for adult learners is seldom accessible. One now defunct class located near Newtownards successfully taught people to write in Ulster-Scots. Other classes have usually failed because of poor choice of tutor by host institutions. Another obstacle to the teaching of good Ulster-Scots writing skills is the widespread perception that all Northern Ireland people know Ulster-Scots anyway. Unfortunately, this is a fallacy.

In more recent issues of Ullans, the editors have worked with new writers on the material they have submitted, to achieve optimum results and aid their future efforts. In addition, articles and poems that contain denser Ulster-Scots have been, and are now increasingly, glossed.

\section{Historical depth}

19 Advocacy for the Ulster-Scots language frequently encounters hostile opposition. One oftrepeated allegation is that Ulster-Scots has been made up by politically-motivated unionist zealots who simply wish to divert funding away from the Irish language ${ }^{12}$. Unfortunately, people active in the sector have often reinforced this view by the circulation of ersatz Ulster-Scots, folk etymologies and English slang spuriously identified as Ulster-Scots.

20 As a counterbalance, the Ulster-Scots Language Society tries to publish older material that will show the authenticity of the language. Even in the first issue of Ullans, some of the oldest published poetry, dating to 1753 , was included ${ }^{13}$. The term "Ulster Scots" is even older: the first known instance of the term, used to define the people, occurs in a source dated 8 October $1640^{14}$. In recent years, the Society has also republished classic prose texts by W. G. Lyttle (1844-1896) and Archibald McIlroy (1859-1915) in response to public demand ${ }^{15}$.

21 Credit for initiating the modern revival of interest in the Weaver Poets, however, must go to a book entitled Rhyming Weavers and other Country Poets of Antrim and Down, the PhD thesis of the late Dr. John Hewitt (1907-1987) adapted for general publication ${ }^{16}$, which appeared almost twenty years before The Ullans Press began its activity. There are gaps in his roll-call of poets, but Hewitt's enthusiasm for these humble "bards" is clear from his text. The same publisher produced a new edition of Hewitt's work in 2004.

\section{Humorous material}

22 A number of the more prolific modern writers feature humorous themes, interspersed with nostalgia. Examples from the USLS publications list are found in the poetry of The Twa Chairlies (Charlie Reynolds and Charlie Gillen) ${ }^{17}$. It is possible that this preference hints at an instinctive defence against ridicule; alternatively, these writers may simply be following a popular theme in the country areas where they live. From empirical observation, there is an interest, particularly in rural parts of Ulster, in public recitations of humorous verse based on observation of the lives of ordinary local people. This is a variety of home-grown entertainment that has almost outlived its time, and it is not 
restricted to Ulster-Scots language areas. In Northern Ireland, most groups that include people over 50 years of age will have at least one person capable of reciting the poetry of W. F. Marshall (from County Tyrone) ${ }^{18}$ or the Crawford Howard monologues ${ }^{19}$.

There is clearly a market for Ulster-Scots language versions of this homespun humour; however, the USLS is wary of over-emphasising it. There is an inherent contradiction in campaigning to have the language taken more seriously while publishing a lot of material that pokes fun at Ulster-Scots ways. Of course, there is a world of difference between Ulster-Scots people writing for the benefit of fellow Ulster-Scots, and those from outside the Ulster-Scots community using humour as a weapon to demean the language and discourage its use.

The pioneer of the academic study of Ulster-Scots, the late Professor Robert J. Gregg $(1912-1998)^{20}$, was a classic example of the former type. Despite his undisputed prominence in the academic world, he retained a love for the comedic traditional poetry, saws and duologues of his east Antrim home. In contrast, the negative type of humour is found in the drawings of Ian Knox, cartoonist for the Irish $\mathrm{News}^{21}$, which have on three occasions caused outrage in the Ulster-Scots community. Press and broadcasting media derision directed at Ulster-Scots is common.

\section{Children's publications}

Scots language publications for children have been of a consistently high standard. The Kist $^{22}$ was a wonderful educational resource for school pupils in the 5 to 14 age group, covering all indigenous language varieties found in Scotland. Subsequent children's publications were produced by the Scots Language Resource Centre in Perth, under Sheila Douglas; and latterly Itchy Coo, a dedicated provider of children's texts in Scots, was responsible for an extensive list including such titles as Precious and the Puggies ${ }^{23}$, a translation of Alexander McCall Smith's Precious and the Monkeys.

Meanwhile, the Ulster-Scots Language Society has been responsible for only two publications exclusively for children. The first was a translation into Ulster-Scots of a dramatic treatment of the Biblical story of Queen Esther ${ }^{24}$. This hardback book was very attractively produced, with excellent illustrations by a local artist. However, it made little impact locally and may well have been before its time. Its production was funded by the Arts Council of Northern Ireland, which also funded that of the second children's book in the series ${ }^{25}$, focusing on the story of King Fergus, sixth century king of Dalriada, after whom Carrickfergus in County Antrim is said to have been named.

In recent years, possibly the best book for younger children was published by the UlsterScots Community Network ${ }^{26}$, and the Society assisted its author with the text.

Unfortunately, even a children's book was not spared a political attack, for a work colleague of the author of Fergus complained to the Arts Council of Northern Ireland that the book was teaching children a discredited account of history. During the subsequent exchange of letters, it was pointed out that the back cover précis states that the story is "based on local traditions and chronicled legends" ${ }^{27}$ and no claim was ever made that it was intended as a factual historical account. The complaint was not upheld; but it was a stressful period for the author, and for The Ullans Press as publisher, and provided a salutary lesson that in the Northern Ireland context the most innocuous desire to teach 
children a little of a regional minority language through the medium of a story based on local legends can suddenly acquire an unexpected political significance.

\section{Language development} rights of authors who generously donate their writings for publication by The Ullans Press. From the first issue of Ullans, copyright has remained with the authors themselves. This policy has caused friction between the USLS and its funding body, the Ulster-Scots Agency.

Matters of language development have suffered greatly from the difficult history of the Ulster-Scots Academy. A detailed treatment of this subject is beyond the scope of the present article. It is sufficient to note that the creation of a fully-fledged electronic corpus of Ulster-Scots literature is still awaited, in addition to the historical dictionary already mentioned. There has been a degree of progress on both projects, due to the commitment of Ulster-Scots Language Society workers.

However, out of all the language development projects, only that relating to Bible translation has reached the publication stage, under the oversight of Wycliffe Bible Translators Philip and Heather Saunders, working in partnership with the Society. The first of the gospels appeared towards the end of $2009^{28}$, and the publication of a volume containing all four is expected in the current year.

\section{Copyright}

At one point, a number of titles in the "Living Writers" series ${ }^{29}$ were ready for publication but, before agreeing to fund the work, the Agency wished to secure the right to reproduce the material concerned on its website. Although capable of relatively easy resolution in any other context, this issue dragged on for approximately two years. The main difficulty was said to relate to "governance" (or the civil service interpretation of responsible use of public money). In the end, the Language Society simply amended the Letter of offer, giving the form of words necessary to bring about the desired objective, and the amended document was accepted without comment by the Agency.

In another instance, a Language Society member had transcribed folksy newspaper columns from a local newspaper published in the early 1900s, for the Ulster-Scots Academy Implementation Group, now defunct. Under the system then operating, he was paid for having undertaken the transcription and signed the rights to it over to the Language Society. Subsequently, USLS officers were taken aback to discover that the Agency had funded publication of a selection from the transcription, which was being distributed free to homes in the North Antrim area together with a CD of someone reading the text ${ }^{30}$. A considerable sum of public money was said to be involved in their production and distribution; however, there was little point in making an issue of the breach of the original agreement with the Language Society. Concern remains that the Ulster-Scots Agency, which, as has been noted, has no specialist knowledge of the language, nevertheless thought it worthwhile to prioritise the publication and free distribution of something that is not a prime example of Ulster-Scots writing. 


\section{A modern dilemma} writings in Ulster-Scots must be mediated to the reader, particularly in view of the modern dilution of the distinctive vocabulary and grammar of the language. For that reason, publications have latterly comprised sections containing context, linguistic commentary and/or glosses ${ }^{32}$. This, it is hoped, will open them up to a wider audience.

\section{And the others?}

41 The Ullans Press claims to be the "original and best" publisher of Ulster-Scots writings. However, others have circulated publications in and on Ulster-Scots since the time of the Belfast/Good Friday Agreement. Perhaps the most visible of these is the newspaper, The Ulster-Scot ${ }^{33}$, published by the Ulster-Scots Agency. This periodical has been useful as a 
guide to community happenings and historical figures and events. However, it has proved a less than satisfactory medium for the language.

The Ulster-Scots Language Society wholeheartedly supported plans to establish the paper during Lord Laird's period as chairman of the Boord (2000-2004), but soon discovered that Ulster-Scots language material submitted by the USLS was not being accurately reproduced. Having ascertained that the editor had no knowledge of the language, the Society offered to edit articles with Ulster-Scots language content free of charge. This offer was summarily rejected. Consequently, USLS contributors lost confidence in the paper and submitted fewer and fewer articles. In the intervening years, the fact that the paper is almost exclusively in English has been commented on in the press, online and at the Legislative Assembly. Another result of the paper's intellectual disengagement from the language has been the inclusion, from sources other than the USLS, of linguistic misinformation, in the form of spurious etymologies and some writings of an embarrassingly low standard. There have been occasional worthwhile Ulster-Scots language articles, but these are the exception.

The most valuable contribution to the canon of modern Ulster-Scots literature from sources other than the Language Society was the Denkschrift published as a tribute to the late Professor Robert J. Gregg ${ }^{34}$. As well as making the fruits of much sound research more generally available, the volume provided a much-needed corrective to the modern misconception that no work of any consequence had previously been done on the orthography of Ulster-Scots. It is a great pity, however, that few language students in particular seem to be aware of its existence.

Translation is the final category of writing in which there has been any significant input from other sources. The Ullans Press has usually preferred to feature material directly written in Ulster-Scots, rather than translations of books or booklets originally written in English. There are two reasons for this. Firstly, it is very much more difficult to make translated material read naturally, as the text has initially been "thought" in another language and it is all too easy for the inexperienced translator to be influenced by that other language's word order and grammar. Secondly, skills and capacity within the Ulster-Scots community are not augmented if the creative process is taking place elsewhere.

Consequently, when the USLS was approached by Michael Everson, an American whose interest is in having Lewis Carroll's book, Alice in Wonderland, translated into as many as possible of the world's languages, the Society did not view it as a priority to spend time on a translation of this text into Ulster-Scots. However, Mr Everson then moved on to another provider, and subsequently the translation appeared ${ }^{35}$. The Society has not regretted its decision.

\section{Lessons for publishers}

It may seem from this study that the obstacles to publication of Ulster-Scots language material are so varied and so wide-ranging as to be nearly impossible to circumvent. No doubt the predecessors of the current Ulster-Scots writers, the Weaver Poets, were similarly exercised, in this case by the problem of financing volumes of their poetry. These were poor people, many of whom were rebels against the state in the insurrection of 1798 , and it was an age when much of the resourcing was done through the patronage 
of titled landowners. A glance at their "collected works" shows that they surmounted the difficulty by obtaining the support of subscribers, whose names are listed in these volumes and who pledged sums of money towards the costs of publication.

Those who look to these Weaver Poets for inspiration do well to be similarly resourceful. Today's activists have to be especially imaginative in order to continue to put good Ulster-Scots texts into the hands of the current generation. They owe no less to the writers of the past, and to the generations yet to come, whose linguistic heritage should not be denied to them.

As well as obstacles, there have been encouragements. For example, over the years Ullans has featured approximately 75 different modern writers in or about Ulster-Scots (including around 10 from outside Northern Ireland), and the work of 19 different historic writers. A comprehensive list of Ulster-Scots publications can be found in the Robert J. Gregg Denkschrift ${ }^{36}$ and more information on the Society's work can be obtained through its website [www.ulsterscotslanguage.com].

\section{NOTES}

1. Periodic Report on Application of the European Charter for Regional or Minority Language in the United Kingdom, 3rd Monitoring Cycle, Chapter 2, section 33, p.9, recognises that UlsterScots is "still largely invisible in public life".

2. For the text of the Agreement, see http://peacemaker.un.org/node/1697. It will be noted that neither of these names appears in the text itself, and the official title is "The Northern Ireland Peace Agreement".

3. John Erskine and Gordon Lucy (eds.), Cultural Traditions in Northern Ireland: Varieties of Scottishness: Exploring the Ulster Scottish Connection, Institute of Irish Studies, Queen's University of Belfast, 1997.

4. Alan Finlayson, "The Problem of 'Culture' in Northern Ireland: A Critique of the Cultural Traditions Group", The Irish Review, $\mathrm{n}^{\circ}$. 20, Winter - Spring 1997, Cork University Press, p. 78.

5. Ullans: The Magazine for Ulster-Scots, nummer 1, Spring 1993, p. 2.

6. For example, the writings of John M Kirk in such articles as, "Two Ullans Texts", in John M Kirk and Dónall P. Ó Baoill (eds.), Language and Politics: Northern Ireland, the Republic of Ireland and Scotland, Belfast Studies in Language, Culture and Politics 1, Belfast, Queen's University, 2000, p. 33-44; and those of Máiread Nic Craith, including, "Contested Identities and the Quest for Legitimacy", Journal of Multilingual and Multicultural Development, 21, 2000, p. 399-413.

7. James Fenton, The Hamely Tongue: A Personal Record of Ulster-Scots in County Antrim, 3rd edition, Belfast, The Ullans Press, 2007.

8. Philip Robinson, Ulster-Scots: A Grammar of the Written and Spoken Language, 2nd edition, Belfast, The Ullans Press, 2007. 
9. James Fenton, Thonner an Thon, Belfast, The Ullans Press, 2000, and On Slaimish, Belfast, The Ullans Press, 2009; Philip Robinson, Alang tha Shore, Belfast, The Ullans Press, 2005, and Oul Licht, New Licht, Belfast, The Ullans Press, 2009.

10. James Orr, Poems on Various Subjects, Belfast, Wm. Mullan \& Son, 1935.

11. See, for example, "Draft Strategy for Ulster Scots Language, Heritage and Culture" [ www.dcalni.org.uk].

12. See, for example, John Kirk, "Language, Culture and Division", Fortnight, n 396, June 2001, p. 18-19.

13. "Scotch poems", in The Ulster Miscellany, Belfast, 1753, p. 369-386.

14. "The Life and Original Correspondence of Sir George Radcliffe, Knt.", p. 209-210, cited in James Seaton Reid's, History of the Presbyterian Church in Ireland, Edinburgh, Waugh and Innes, 1834, vol. 1, p.271.

15. W. G. Lyttle, Betsy Gray or Hearts of Down: A Tale of Ninety-Eight, Belfast, The Ullans Press, 2008; Archibald Mcllroy, The Auld Meetin'-Hoose Green, Belfast, The Ullans Press, 2011.

16. Belfast, Blackstaff Press, 1974. Funding from the Arts Council of Northern Ireland supported this publication.

17. Charlie Gillen, The Wizard's Quill, Belfast, The Ullans Press, 2005; Charlie Reynolds, Mae Granfeyther's Tunge, Belfast, The Ullans Press, 2005.

18. See, for example, W F Marshall, Livin' in Drumlister, Belfast, Blackstaff Press Ltd., 1983.

19. See, for example, Crawford Howard, Billy Ritchie and Maud Steele (Liz Weir ed.), Stand up and Tell them, Banbridge, Adare Press, 1991.

20. For a bibliography of the writings of R. J. Gregg, and the texts of a selection of his principal works, see Anne Smyth, Michael Montgomery and Philip Robinson (eds.), The Academic Study of Ulster-Scots: Essays for and by Robert J. Gregg, Holywood, National Museums and Galleries of Northern Ireland, 2006.

21. Most recently, in the edition of 23 November 2011.

22. Compiled by the Scottish Consultative Council on the Curriculum, Robbie Robertson (ed.), Glasgow, Nelson Blackie, 1996.

23. Alexander McCall Smith, Precious and the Puggies: Precious Ramotswe's Very First Case, Edinburgh, Black and White Publishing, 2011.

24. Philip Robinson, Esther, Quaen o tha Ulidian Pechts, Belfast, The Ullans Press, 1997.

25. Philip Robinson, Fergus an tha Stane o Destinie, Belfast, The Ullans Press, 1999.

26. Matthew Warwick, Fergie an Freens oan tha fairm, Belfast, Ulster-Scots Community Network, 2011.

27. Philip Robinson, op. cit., outer back cover.

28. Guid Wittens frae Doctèr Luik: The Gospel according to Luke in Ulster-Scots, Belfast, The Ullans Press, 2009.

29. For example, John M'Gimpsey Johnston, Blethers fae Bellyhie, Belfast, The Ullans Press, 2005.

30. See report in the Ballymoney Times, 10 December 2008, headed "The Bushside Letters are being delivered to homes".

31. Belfast, The Ullans Press, 2011. 
32. For example, Archibald McIlroy, The Auld Meetin'-Hoose Green, Belfast, The Ullans Press, 2011, which included a biography of the author and a linguistic commentary.

33. Issues dating back to 2009 from the present can be viewed at [ www.ulsterscotsagency.com/ulster-scots-publications/the-ulster-scot/].

34. Anne Smyth, Michael Montgomery and Philip Robinson (eds.), The Academic Study of Ulster-Scots, op. cit.

35. Lewis Carroll (Anne Morrison-Smyth trans.), Alice's Carrànts in Wunnerlan, Evertype, Glencarraig, Co. Mayo, 2011.

36. John G. W. Erskine and Michael Montgomery, “Annotated Bibliography of Ulster-Scots Language and Literature", in The Academic Study of Ulster-Scots, op. cit., p. 99.

\section{ABSTRACTS}

Access to authentic written Ulster-Scots material is essential to its progress as a European Regional Minority Language. This study examines the competing pressures governing its publication, within the unusual political system in Northern Ireland. It has been informed by empirical observation over almost twenty years of practical experience. Implications of the findings concern the need for determination and resourcefulness in combating the obstacles to publication of the necessary works.

Afin d'assurer le progrès de l'Ulster-Scots en tant que langue européenne régionale minoritaire, il est essential de pouvoir avoir accès à des écrits authentiques. Cet article explore les facteurs concurrents qui influencent la publication en Ulster-Scots dans le cadre du système politique hors norme en place en Irlande du Nord. Cette étude est le fruit de l'observation empirique et d'expérience pratique dans ce domaine sur une période de presque vingt ans. Elle conclut à la nécessité de faire preuve de détermination et d'inventivité pour surmonter les obstacles s'opposant à la publication des ouvrages nécessaires.

\section{INDEX}

Keywords: Ulster-Scots, languages in Ireland - Ulster-Scots, collective identity, languages in Ireland - language policy, Northern Ireland, cultural heritage

Mots-clés: langues en Irlande - Ulster-Scots, identité collective, Irlande du Nord, langues en Irlande - politiques linguistiques, Ulster-Scots, héritage culturel

\section{AUTHOR}

\section{ANNE SMYTH}

Chairman of the Ulster-Scots Language Society 